OPEN ACCESS

Edited by: Sujith K. Joseph,

Baylor College of Medicine,

United States

Reviewed by:

Giedre Krenciute,

St. Jude Children's Research

Hospital, United States

Evelien Smits,

University of Antwerp, Belgium

*Correspondence:

Analiz Rodriguez

arodriguez@uams.edu

Specialty section:

This article was submitted to Cancer Immunity and Immunotherapy,

a section of the journal

Frontiers in Oncology

Received: 20 April 2020

Accepted: 22 July 2020

Published: 12 August 2020

Citation:

Patterson JD, Henson JC Breese RO, Bielamowicz KJ and Rodriguez A (2020) CAR T Cell

Therapy for Pediatric Brain Tumors.

Front. Oncol. 10:1582.

doi: 10.3389/fonc.2020.01582

\section{CAR T Cell Therapy for Pediatric Brain Tumors}

\author{
John D. Patterson', Jeffrey C. Henson', Rebecca O. Breese², Kevin J. Bielamowicz ${ }^{3}$ and \\ Analiz Rodriguez ${ }^{1 *}$ \\ ${ }^{1}$ Department of Neurosurgery, University of Arkansas for Medical Sciences, Little Rock, AR, United States, ${ }^{2}$ Department \\ of General Surgery, Wake Forest Baptist Medical Center, Winston-Salem, NC, United States, ${ }^{3}$ Division \\ of Hematology/Oncology, Department of Pediatrics, Arkansas Children's Research Institute, Little Rock, AR, United States
}

Chimeric Antigen Receptor (CAR) T cell therapy has recently begun to be used for solid tumors such as glioblastoma multiforme. Many children with pediatric malignant brain tumors develop extensive long-term morbidity of intensive multimodal curative treatment. Others with certain diagnoses and relapsed disease continue to have limited therapies and a dismal prognosis. Novel treatments such as CAR T cells could potentially improve outcomes and ameliorate the toxicity of current treatment. In this review, we discuss the potential of using CAR therapy for pediatric brain tumors. The emerging insights on the molecular subtypes and tumor microenvironment of these tumors provide avenues to devise strategies for CAR T cell therapy. Unique characteristics of these brain tumors, such as location and associated morbid treatment induced neuro-inflammation, are novel challenges not commonly encountered in adult brain tumors. Despite these considerations, CAR T cell therapy has the potential to be integrated into treatment schema for aggressive pediatric malignant brain tumors in the future.

Keywords: chimeric antigen receptor T cell, pediatric brain tumor, medulloblastoma, ependymoma, ATRT, pediatric glioma, immune therapy, adoptive cell therapy

\section{INTRODUCTION}

Chimeric antigen receptor (CAR) $\mathrm{T}$ cells are a form of adoptive cell therapy used for immunotherapy. CAR T cells were initially FDA approved in 2017 for hematological malignancies, however, many preclinical and clinical studies have shown efficacy of CAR T cells for solid tumors including glioblastoma, medulloblastoma, and ependymoma (1-3). Pediatric central nervous system (CNS) cancers remain the leading cause of pediatric cancer related death, thus there is an urgent need to develop new therapies (4). These new therapies need to be specifically directed to malignant cells and limit off target cytotoxicity inherent in chemotherapeutics while having a strong, sustained cytotoxic effect on cancer cells to minimize recurrence. CAR-T cells have the potential to accomplish these goals. In this review, we discuss the current progress in CAR T cell development for specific pediatric brain tumors as well as future implementation strategies.

\section{Overview of CAR-T Cell Targeting}

The concept of engineering chimeric antigen receptors (CAR) has been around for over 25 years, and entails combining a single-chain variable fragment $(\mathrm{scFv})$ of an antibody with the $\mathrm{T}$ cell receptor (TCR) signaling domain $\mathrm{CD} 3$, thus conferring antibody like antigen recognition to $\mathrm{T}$ cell cytolytic activity $(5,6)$. This ingenuity allows for the recognition of a target antigen without 
presentation by major histocompatibility complex (MHC) (5). However, in order for the $\mathrm{T}$ cell to carry out its cytolytic activity, proliferate and maintain persistence in the local microenvironment, co-stimulation is still necessary (7). In nature these co-stimulatory signals are provided by the antigen presenting cell, but in engineered CAR T cell constructs multiple co-stimulatory domains can be included to promote $\mathrm{T}$ cell functionality $(8-10)$.

For applications of CAR $\mathrm{T}$ cells in cancer treatment, the engineered target is ideally only present on the tumor and not on normal cells thus limiting off target therapeutic effects (1). CAR T cell therapy became FDA approved in 2017 for B cell malignancies by targeting CD19 (11). The applications for CAR T cells continues to expand in the clinical setting especially in the treatment of hematological malignancies (12). Multiple clinical trials are in place for evaluating the efficacy of CAR T cell therapy in solid tumors but to date CAR therapy for this indication is not FDA approved. Many obstacles are present that hinder the efficacy of CAR T therapy in solid tumors which includes but are not limited to difficulty in trafficking to the tumor site, presence of an immunosuppressive environment, toxicity, and tumor antigen heterogeneity (13).

Solid tumors in the brain present further difficulties due to the semipermeable properties of the blood brain barrier (BBB) which limits the delivery of many therapeutics (14). The BBB is comprised of specialized endothelial cells that prevent entry of large hydrophophilic molecules and unwanted cells from entering the brain. Brain tumors disrupt the $\mathrm{BBB}$ to form the blood- tumor barrier (BTB) which has heterogenous perfusion and permeability throughout the tumor and also hinders the delivery of therapeutics (15). CAR T cell infusion to the brain can include delivery via the blood, cerebral spinal fluid (CSF), or locally in the tumor cavity (Figure 1). Brain tumors are currently the most common solid tumor types undergoing clinical trial testing for CAR T cell efficacy and have shown early promise in the treatment of glioblastoma (GBM) (16). In this review, we focus on pediatric brain tumors as novel interventions are needed given the grim prognoses for many patients.

\section{PEDIATRIC BRAIN TUMORS}

\section{Medulloblastoma}

Medulloblastoma is the most common malignant brain tumor in children (10-20\% of all pediatric brain tumors) with
A

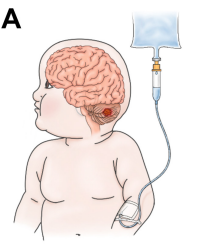

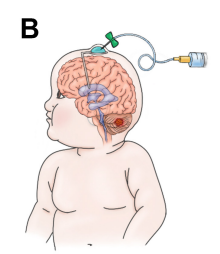

C

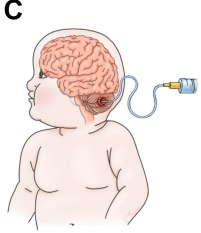

FIGURE 1 | Options for infusion of CAR-T cells. (A) Intravenous (IV), (B) Intrathecal/Ventricular (IT), (C) Intratumor/cavity (IC). an incidence rate of 6.0 per million in patients 1-9 years old (17). Until recent years, medulloblastoma prognosis and classification was primarily stratified on a histological basis, as well as characteristics such as age and metastatic status (18). With increasing accessibility to advanced molecular genetic techniques, medulloblastoma has been further classified based on its distinct molecular subtypes (WNT, SHH, Group 3, and Group 4 ), shedding new light on potential therapeutic targets (19). These tumors develop in the cerebellar vermis and thus are exclusively in the posterior fossa (20).

The current standard of care for medulloblastoma remains surgical resection, craniospinal irradiation, and chemotherapy. The expected 5-year survival is 70-75\% amongst children greater than 3-years-old (21-26). New risk stratification groups and survival outcomes have been proposed taking into account the molecular subtypes. After review of data from several cohorts of the 4 molecular subtypes, Ramaswamy et al. proposed a four group stratification scheme: low risk (>90\% survival), standard risk (75-90\% survival), high risk (50-75\% survival) and very high risk ( $<50 \%$ survival). The WNT subtype and MYCN-amplified SHH subtype had the best and worst overall survival, respectively (27). The prognostic information provided by molecular subtyping can influence treatment specifically the need for adjuvant radiation given the increased risk of neurocognitive impairment in children (28).

\section{Molecular Subtypes}

The WNT subgroup of medulloblastoma, known for its excellent long-term prognosis compared to other subgroups, has mortality outcomes related more to complications of treatment or secondary neoplasms rather than tumor recurrence $(19,29)$. The classic WNT pathway defects in this subgroup occur through somatic deletions of CTNNB1 on chromosome 6 (encoding b-catenin), or monosomic deletions of chromosome 6 , and thus have positive immunohistochemical staining for b-catenin (30). Additionally, germline mutations of WNT pathway inhibitor APC are associated with Turcot syndrome and associated medulloblastoma (31). Current studies in this subgroup aim to improve excellent survival outcomes while decreasing whole brain and spine radiation doses (NCT01878617, NCT02724579).

The SHH (sonic hedgehog) group is characterized by mutations resulting in activation of the $\mathrm{SHH}$ pathway. Germline mutations in $\mathrm{SHH}$ receptor $\mathrm{PTCH}$ (Gorlin syndrome) and SHH inhibitor SUFU predispose to medulloblastoma, especially infantile forms (32-36). This activation occurs primarily through somatic PTCH1/SMO/SUFU mutations, as well as amplifications of GLI1, GLI2, and MYCN $(34,37,38)$. Tumors of this group occur in all ages and is the predominant subgroup in children $<3$ years of age and adults. Outcomes are good in young children with a less favorable outcome in older children and adults, especially with TP53 mutations $(27,39)$.

Group 3 tumors are characterized primarily by MYC amplification, as opposed to MYCN amplification characteristic of the SHH subgroup (40-42). Amplification of oncogene OTX2 can also be seen in group 3, as well as group 4 tumor (43-45). Furthermore, while the pathogenesis is not yet clear, these tumors frequently overexpress genes involved in retinal development and 
GABAergic pathways (40-42). Overall, these tumors frequently metastasize and thus have the worst outcome of all subgroups $(19,27)$.

Group 4 tumors remain the least understood of the subgroups, however, they make up $>30 \%$ of all medulloblastomas (19). Isochromosome $17 \mathrm{q}$ is a common feature of group 4 tumors, occurring in $66 \%$ of tumors $(41,46)$. Also notable is the high incidence of cytogenetic loss of the X chromosome in $80 \%$ of females with group 4 medulloblastomas (40). These tumors frequently metastasize and can be high risk depending on their genetic features (27). Further research on the etiopathogenesis of medulloblastoma is ongoing.

\section{Antigenic Targets}

Receptor tyrosine-protein kinase ERBB2 (HER2) expression is most well-known for its role in a subset of breast cancers; however, HER2 expression is seen in approximately $40 \%$ of medulloblastomas (47). Given that ERBB2 protein is not detected in normal brain (48), this makes it an attractive target for CAR $\mathrm{T}$ cell therapy. Treatment with monoclonal antibodies targeting HER2 was ineffective in medulloblastoma likely due to lower expression profiles than in breast cancer and lack of HER2 gene amplification (49).

Early application with first generation CAR $\mathrm{T}$ cells (i.e., CAR $\mathrm{T}$ cells with an intracellular $\mathrm{CD} 3$ zeta domain and no co-stimulatory domain) in targeting HER2 showed promise by demonstrating effective targeting and regression of medulloblastomas in an orthotopic xenogenic mouse model (49). Efficacy of this study was likely limited by reliance on use of first generation CD3 constructs. Nellan et al. recently showed improved response and durable regression when using second generation CAR T cells with 4-1BB co-stimulation administered regionally to target HER2 in a preclinical xenograft model (50). These second generation CAR T constructs have shown improved persistence, increased $\mathrm{T}$ cell activation and decreased $\mathrm{T}$ cell exhaustion (51).

B7-H3 (CD276) overexpression has been found in a variety of human cancers, including lung adenocarcinoma, craniopharyngioma, neuroblastoma, medulloblastoma, glioma, ovarian cancer, pancreatic cancer, and acute myeloid leukemia. This pan-cancer antigen has absent or low in normal tissues making it an ideal CAR T cell target (52). In xenograft models of pediatric osteosarcoma, medulloblastoma, and Ewing sarcoma, B7-H3 CAR T cells demonstrated efficacy against tumors high surface target antigen density (53). Given the heterogeneity of cell surface antigen expression in brain tumors, such as glioblastoma (GBM), multivalent CAR T cells have been designed. These CAR $\mathrm{T}$ cells are capable of targeting multiple antigens simultaneously. Trivalent targets to EPHA2, HER2, and IL13R $\alpha 2$ with CAR T cells has demonstrated efficacy in preclinical models of recurrent medulloblastoma and GBM $(3,54)$.

Targeting cancer testis antigens is of interest given their limited normal tissue expression on testicular germ cells and placental trophoblasts, thereby decreasing off target effects (55). The cancer testis antigen, PRAME, has been estimated to be expressed in up to $80 \%$ of medulloblastomas and could potentially serve as an immunotherapeutic target (47). Many cancer testis antigens remain MHC restricted immune targets making widespread application difficult due to the vide variance of MHC alleles across populations. However, Orlando et al. recently showed some success in orthotopic medulloblastoma models using CAR-T cells specific for the PRAME-derived peptide SLL (56). This peptide, which is presented in context of HLA- $A^{*} 02$, is thought to be present in up to $48.4 \%$ in caucasians and $22.6 \%$ in black ethnic groups (57).

\section{Tumor Microenvironment}

The tumor microenvironment is comprised of tumor-infiltrating immune cells, fibroblasts, and endothelial cells, as well as a dynamic extra-cellular matrix which all can modulate tumor progression and the response to immunotherapy (58). The tumor microenvironment in solid tumors is typically immunosuppressive and impairs the efficacy of immunotherapy including CAR T cell therapy (59). Pediatric brain tumors are less immunosuppressive compared to their adult counterparts (60). The tumor microenvironment is still being characterized in medulloblastoma but there are differences in tumor infiltrating leukocytes between molecular subtypes. SHH group tumors are characterized by higher immune cell infiltration such as tumor associated macrophages (TAMs) and increased expression of inflammation-related genes compared to group 3 and 4 tumors $(61,62)$. Interestingly, Pham et al. measured immunosuppressive subsets of CTLA-4 or PD-1-expressing T cells in murine Group 3 tumors and found they contained higher percentages of PD$1+$ and CD8+ T cells (62). In xenograft models, a significant survival benefit was only present in group 3 medulloblastoma subtypes treated with anti-PD-1 alone or in combination with anti-CTLA-4 $(62,63)$. The differential response to anti-PD-1 blockade observed in group 3 medulloblastoma suggests that the PD-1/PD-L1 environment is a key immunoregulatory pathway.

In previous small human cohort studies, there was no subgroup specific patterns of tumor infiltrating lymphocytes observed $(64,65)$. Murata et al. reported that $56 \%$ of cases had high expression of PD-L1 and was actually associated with low CD8 + T cell infiltration and poor prognosis (66). However, two other cohort studies reported no significant expression of PD-L1 in any of the studied cases of medulloblastomas (64, 65). A recent, more comprehensive study, by Bockmayr et al. which included 763 medulloblastoma cases did find significant differences in tumor microenvironments between subgroups using gene expression data analysis (67).

\section{Pediatric Ependymoma}

Ependymomas comprise $5.2 \%$ of pediatric CNS tumors making these tumors the third most common in the pediatric population $(68,69)$. These tumors arise from cells along the lining of the cerebral ventricles or the spinal cord central canal. For the purposes of this review we will only discuss intracranial ependymomas. Ependymomas are classified by the World Health Organization (WHO) as grades I, II, and III based on their grade of anaplasia (70). Standard therapy includes aggressive gross total resection (GTR) is combination with radiotherapy. Merchant et al. showed that conformational radiation therapy (CRT) significantly improves survival in children and is similar 
across pedatric age groups including patients less than 3 years of age $(71,72)$. Aggressive GTR is critical in ependymoma patients to prevent recurrence and can sometimes be difficult given local infiltration. Recurrent disease can be difficult to manage and overall survival at 5 years is as low as $37 \%$ for recurrent tumors $(72,73)$. While the utility of radiotherapy has clearly been shown in treating ependymomas in children, the benefit with upfront chemotherapy is less understood. However, a recently closed trial exploring this will soon be reporting results (COG trial ACNS0831).

\section{Molecular Supbtypes}

With advances in molecular genetics, we now know that ependymomas have four subtypes, two in the posterior fossa and two in the supratentorial space. Posterior fossa ependymomas (PFE) have 2 distinct groups, PFE group A (PFA) and group B (PFB), each of which have distinct demographics, epigenetics, and outcomes $(74,75)$. PFA tumors are typically only found in infants, while PFB occurs equally in adults and adolesents (76). Patients with PFA have increased risk of recurrence and worse overall survival (75).

Supratentorial ependymoma are divided into two subtypes based on mutational drivers namely, C11orf95-RELA (RELA) fusions and YAP1 (YAP) fusions. These two supratentorial subtypes are genetically and clinically distinct with RELA patients having a poorer prognosis than those with YAP (76).

\section{Antigenic Targets}

Studies have demonstrated increased expression of EphA2, IL$13 \mathrm{R} \alpha 2$, HER2 and Survivin in ependymomas $(77,78)$. Therefore, these antigens may be potentially effective targets in CAR T cell mediated therapy clinically. CAR-T cells with trivalent targets to EPHA2, HER2 and IL13R $\alpha 2$ did show efficacy in xenograft models of ependymomas (3). While ependymomas may hold favorable outcomes with traditional therapy in some pediatric patients, recurrence is often fatal and further work in novel treatments and immunotherapy is needed.

\section{Tumor Microenvironment}

Similar to medulloblastoma, tumor microenvironment characteristics directly correlate with molecular subgroup. PFA tumors have enrichment in inflammatory response genes in comparison to PFB tumors (79). IL6/STAT3 pathway activation and crosstalk between cancer cells and myeloid cells is a potential mechanism underlying the PFA tumor phenotype. This pathway could potentially be used as a therapeutic target (80). RELA ependymomas have higher PD-L1 gene expression in comparison to other subtypes indicating a potential increased immunosuppression in this group (81). Further immune phenotyping of ependymomas with microarrays demonstrated that myeloid cells in the microenvironment have a more M1 or pro-inflammatory phenotype (82). Charactization of primary and matched recurrent ependymoms demonstrate that some tumors did change molecular subtype and inflammatory profiles upon recurrence (83). This indicates that the microenvironmnet can change during a patient's treatment course, a critical consideration when choosing a therapy such as CAR T cells.

\section{Atypical Teratoid/Rhabdoid Tumors}

Atypical teratoid rhabdoid tumors (ATRTs) are aggressive embryonal CNS tumors that occur in 0.66 per 100,000 children. These tumors usually occur in children less than 4 years old and can occur in the posterior fossa or the supratentorium. The majority of tumors in children younger than 1 year occurred infratentorially. ATRT dianosis portends a grave diagnosis with a median survival less than 1 year after diagnosis for most patients (84-86). No standard treatment exists for this tumor but surgical resection is indicated. Given the young age of the patient at presentation, radiation treatment can lead to severe neurocognitive deficits. Despite newer therapies such as intensified multimodal therapy with whole craniospinal irradiation $(87,88)$ or high-dose chemotherapy with stem-cell rescue $(89,90)$ showing improved survival, they come with significant treatment-related morbidity and mortality (91). With the further classification of ATRTs using integrated (epi)-genomic analysis, use of targeted/biological agents may show further promise for some subtypes of ATRTs $(92,93)$.

\section{Molecular Subtypes}

The hallmark of ATRTs is biallelic mutations of SMARCB1 (INI1/hSNF5/BAF47), or rarely SMARCA4, both of which are involved in the SWItch/Sucrose Non-fermentable chromatin remodeling complex (94). Loss of one copy of the entire chromosome 22 or a deletion or translocation specifically involving chromosome band 22q11.2 has been described (95). Recent epigenetic studies have further subdivided ATRT into three methylation subgroups, ATRT-SHH, ATRT-TYR, ATRTMYC, each of which has characteristic locations and methylation patterns (96).

\section{Antigenic Targets}

To date, no definitive ATRT neoantigens have been described, however, preclinical data with cancer stem cells and tyrosine kinase inhibitors in ATRTs may highlight potential antigens for CAR-T targeting and trafficking. Cancer stem cells (CSCs) are subpopulations of tumors cells thought to be associated with treatment failure, tumor recurrence, and metastasis of many cancers primarily due to their quiescence, migratory ability, resistance to drug therapy, and immune evasion (97). Use of patient-derived xenografts (PDXs) to identify and isolate human (CSCs)/tumor-initiating cells (TICs) demonstrated distinct gene signatures associated with CSCs/TICs in malignant rhabdoid tumors (98). Two of these overexpressed genes, CXCL5/CXCL6, may have potential for adjuvant CAR-T therapeutic targeting.

CXCL5/CXCL6 are both chemokine proteins thought to play a role not only in chemotaxis, but angiogenesis and tumorigenesis in many cancer types (99-101). CXCL5 has recently come to the forefront in research for its involvement in proliferation, migration, invasion, and immune evasion in multiple cancer types. Integrated proteomics data suggests that these chemokines are not normally expressed in nervous system tissues, a key factor in trafficking and minimizing off-tumor toxicity for ATRT therapy $(102,103)$. While these ligand are not viable targets, their receptors could potentially be used as targets for adoptive cell therapy. 
Another potential antigenic target for CAR-T therapy is PTK7, a RTK family member, single-pass transmembrane receptor that lies at the signaling crossroads of WNT, VEGF, and stem cell function (104). Recent studies have shown a significant increase in PTK7 RNA expression levels in ATRT tumors, with subsequent repression of proliferation and viability of ATRT cells by vatalanib, which target multiple tyrosine kinases, and siRNAmediated PTK7 knockdown, respectively (105). Preclinical data with antigen-drug conjugate, anti-PTK7 (PF-06647020), in breast, ovarian, and non-small cell lung cancer, shows that PTK7 targeting of CSCs and the tumor microenvironment induces direct and indirect anti-tumor effects, by reducing tumor initiating cells and inducing sustained tumor regression (106).

There are many ongoing and completed clinical trials for patients with ATRTs involving combination therapies, biological agents, and enzyme inhibitors, as well as molecular genetics studies. Much work is needed in preclinical studies to further delineate neoantigens for CAR-T cell targeting in this aggressive pediatric brain tumor.

\section{Tumor Microenvironment}

ATRT are rare tumors and therefore studies on characterizing the tumor microenvironment are limited. There is critical crosstalk between mesenchymal stromal cells and ATRT cancer cells in the microenvironment that leads to the promotion of cancer cell migration (107). The tumor immune microenvironment in ATRTs appears to have some unique features. Tumor immune phenotyping demontrated that ATRTs have significantly increased CD8 $\mathrm{T}$ cells in comparison to GBMs (108). Similar to other pediatric tumors, the immune infiltrate composition corresponds with the molecular subtype. Macrophages predominantly infiltrate the ATRT-SHH and ATRT-MYC subtypes and correlate with poor prognosis and treatment resistance (109). These data again indicate that therapeutic strategies must take into account the subtype classification and its respective immune microenvironment properties in pediatric brain tumors.

\section{Pediatric High Grade Gliomas}

Pediatric High-Grade Gliomas (pHGGs) represent less than 20\% of tumors in this population, and are comprised primarily of anaplastic astrocytomas (AA, WHO grade III), glioblastoma (GBM, WHO grade IV), and the newly defined Diffuse Midline Glioma (DMG, WHO grade IV) (110-114). Pediatric nonbrainstem/midline glioblastomas (pNMGs) are often cortical and thus treated with aggressive combinations of surgery, chemotherapy, and radiation due to poor prognosis (114). Even with gross total resection and chemotherapy, 3-year event free survival is reported to only be $11 \%$ in children with high-grade pNMG (115).

The 2016 WHO classification of CNS tumors introduced a new classification known as H3 K27M-mutant diffuse midline gliomas (DMG), which refers to the specific lysine-to-methionine substitution at position 27 in histone $3(70,112,116)$. These tumors, as their name suggests, arise in midline structures such as the thalamus, brainstem, and spinal cord. They carry a dismal prognosis due to the eloquent location of these tumors making surgery not feasible. The DMG classification thus includes tumors previously referred to as diffuse intrinsic pontine glioma (DIPG).

No standard therapy currently exists for DMG. Treatments include radiation therapy $(117,118)$, targeted chemotherapy $(119,120)$, and several types of adjuvant therapy capable of targeting cellular mechanisms of tumor proliferation, cell cycle progression, angiogenesis and DNA repair (121). Due to the difficult anatomical location of these tumors, surgical resection and even biopsies for tissue characterization, remains uncommon.

\section{Molecular Subtypes}

In contrast to adult gliomas, pediatric non-brainstem/midline glioblastomas (pNMGs) in children more often have TP53 mutations, as opposed to EGFR or PTEN alterations (114, 122). Glioblastomas in children however, almost exclusively arise de novo compared to the secondary development in IDH-mutants from low grade gliomas in adults (122). NMGs in children are also associated with genetics syndromes such as Turcot syndrome, Li-Fraumeni syndrome, and Neurofibromatosis type 1 , all of which have their own known associated mutations in the context of tumor development.

In pediatric high-grade gliomas, approximately $40 \%$ are associated with TP53 mutations, and low p53 expression correlates with improved 5-year progression-free survival (114, 122). Overall, compared to adult high-grade gliomas, pNMGs are less likely to have EGFR gene amplification and less likely to have mutations within the PTEN tumor suppresor gene, although correlations with prognosis and clincial significance are limited (123-125).

Due to the mortality of DMG tumors and difficulty of surgical resection, many clinical trials have attempted to target genetic mutations in the tumor. Early trials showed little success as many targeted the genetic mutations known to adult glioblastomas (126). As more genetic studies have been completed, there are clear differences in gene expression that distinguish DMG from both adult glial tumors and supratentorial pediatric gliomas $(127,128)$. The first of these differences to be uncovered was that nearly $80 \%$ of DIPG tumors contained frequent histone 3 mutations (K27M-H3.3 or K27M-H3.1) (111, 112, 116). Later studies further subcatagorized DIPGs into three molecularly distinct subgroups (H3-K27M, Silent, and MYCN) (129).

\section{Antigenic Targets}

Antigen targeting potential in high grade gliomas is currently the most robust due to translation of research from adult highgrade glioma counterparts. The main antigen targets in adult gliomas inlude: IL13R $\alpha 2$, EphA2, EGFRvIII, and HER2 (1). CD70, a member of the tumor necrosis factor receptor family, and podoplanin (PDPN), a type I transmembrane mucin-like glycoprotein, have also been recently identified as a CAR T cell target in glioma $(130,131)$. Table 1 summarizes antigen targets for pediatric brain tumors including pHGG. While pediatric clinical trials are in progress that include these antigens, recruitment is more limited due to the difference in antigen expression seen between adult and pediatric high-grade gliomas. However, some activity has been seen in the pediatric population. 
TABLE 1 | Primary antigens targeted in CAR-T therapy for pediatric brain tumors.

\begin{tabular}{|c|c|c|c|}
\hline Antigen & Tumor expression & Function & References \\
\hline EGFRVIII & Glioblastoma, Ependymoma, Medulloblastoma & $\begin{array}{l}\text { Brain development and is associated with tumor development } \\
\text { and progression }\end{array}$ & $(186,187)$ \\
\hline HER-2 & $\begin{array}{l}\text { Glioblastoma, Ependymoma, Medulloblastoma, metastatic } \\
\text { tumors }\end{array}$ & Cell cycle homeostasis & $(49,54,132)$ \\
\hline $\mathrm{B} 7-\mathrm{H} 3$ & $\begin{array}{l}\text { Diffuse Midline gliomas, medulloblastoma, and most pediatric } \\
\text { solid tumors }\end{array}$ & Potent immune inhibitory functions & $(53,136)$ \\
\hline GD2 & Primarily Diffuse Midline Gliomas, neuroblastoma, melanoma & Attachment of tumor cells to extracellular matrix proteins & $(138,188)$ \\
\hline IL13RA2 & High-grade glioma, Ependymoma, Medulloblastoma & Apoptosis escape mechanism & $(54,189,190)$ \\
\hline EPHA2 & Gliomas, Ependymoma, Medulloblastoma & $\begin{array}{l}\text { Enhances tumorigenesis, tumor cell migration and } \\
\text { invasion, angiogenesis, and metastasis }\end{array}$ & $(54,191,192)$ \\
\hline SURVIVIN & Ependymoma, glioma & Apoptosis inhibitor protein & $(142)$ \\
\hline PRAME & Medulloblastoma & Inhibits retinoic acid signaling & $(47)$ \\
\hline CD 70 & Glioma & Tumor necrosis factor receptor family & $(130)$ \\
\hline PDPN & Carcinoma, sarcoma, seminoma, brain tumors & Transmembrane glycoprotein & $(151)$ \\
\hline
\end{tabular}

A prospective trial including 17 adult and adolescent patients with relapsed or refractory glioblastoma included an adolescent patient with an objective response after systemically administered HER2 CAR T cells (132).

In pediatric diffuse midline gliomas, both B7-H3 and GD2 specific CAR-T cells, which are highly expressed in DMGs, are also currently targets in clinical trials recruiting pediatric patients (NCT04185038, NCT0409979). B7-H3 is a transmembrane protein that belongs to the B7 immune co-stimulatory and co-inhibitory family, has potent immune inhibititory function $(133,134)$. Studies have shown that it downregulates T-cell activation and INFg, and correlates with fewer tumor-infiltrating lymphocytes, faster cancer progression, and poor clinical outcome in multiple malignancies $(135,136)$. In one study, it was demonstrated that $100 \%$ of DIPG specimens were B7H3 immunoreactive, and mRNA expression was significantly higher in DIPG samples vs juvenile pilocytic astrocytoma or normal brain (137). Majzner et al. demonstrated that B7-H3 CAR $\mathrm{T}$ cells in mice significantly prolonged survival in both medulloblastoma and DIPG xenografts through production of IFNg, TNFa, and IL2 (53).

A recently published study demonstrated the potent antitumorgenic capabilities of CAR-T cells targeted to pediatric diffuse midline gliomas (138). In these tumors, the presence of the H3-K27M mutation correlated with high levels of GD2 diganglioside expression. Many immunotherapies targeting GD2 expression are being investigated in both preclinical and clinical trials for a variety of neurologic conditions including neuroblastoma (139-142). To date, CAR-T cell therapies targeting GD2 expression in neuroblastoma have been well tolerated in many of these clinical trials (139-141).

Due to the known heterogenicity of high-grade gliomas and potential for antigen escape, multi-valent immunotherapy could prove to be a superior approach in treating recurrent gliomas in both adult and pediatric populations. Pollack et al. showed feasibility, tolerability, and some evidence of efficacy in using a trivalent peptide vaccine targeting EphA2, IL13R $\alpha 2$, and survivin in pediatric malignant gliomas (143). Similar preliminary work has also shown potential efficacy for pediatric and adult ependymomas (77). Early CAR-T studies showed the benefit of targeting multiple antigens and decreasing tumor antigen escape (144). Bielamowicz et al. has also demonstrated that trivalent CAR-T cells targeting HER2, IL13R $\alpha 2$, and EphA2 demonstrated superior antitumor activity in GBM patient derived xenografts compared to patient-specific single valent and bivalent models (54). A multivalent is particularly useful in HGG given the tumor heterogeneity of antigen expression which can change over time following CAR T cell therapy (145).

\section{Challenges in the Microenvironment}

pHGGs have been shown to differ from their adult counterparts through the presence of varying somatic histone modifications (110-112). Differential genetic expression between adult and pediatric gliomas result in proteomes with varied biomarker expression with subsequent influences on the tumor microenvironment. Although still controversial, it is thought the pHGGs may arise from neural precursor cells of the oligodendroglial lineage $(113,146,147)$. These types of tumors have been shown to possess distinct discrete patterns of spatial and temporal development that correspond with periods of developmental myelination within the pediatric and adolescent brain $(110,113,148,149)$.

In adult gliomas, the heterogenity of both antigen expression and the tumor microenvironment proves to be a main hurdle in using adoptive cell therapies like CAR-T cells (1, 150). Genetic sequencing of spatially different regions of GBMs has shed light on these regional niches within the tumor containing multiple cell types and functions $(151,152)$. As with adult glioma tumors, infiltrating immune cells play an important role in the makeup of the pediatric tumor microenvironment. Although the knowledge regarding the functional roles of such cells in pediatric gliomas remain incomplete, in mouse models of lowgrade pediatric gliomas, tumor associated macrophages have been implicated in promotion of tumor cell proliferation (153, 154). Similarly, in adult gliomas, the amount of infiltrating TAMs that are CD68 + increases with increasing tumor grade (155). This signifies a correlation between immune cell presence within the tumor microenvironment and tumor malignancy and growth. 
TABLE 2 | Ongoing clinical trials using chimeric antigen-receptor T-cells (CAR-T) for pediatric brain tumors.

\begin{tabular}{|c|c|c|c|c|c|c|c|}
\hline NCT\# & Phase & Study Name & $\begin{array}{l}\text { Responsible } \\
\text { party }\end{array}$ & Target & $\begin{array}{l}\text { Additional } \\
\text { agents/therapies }\end{array}$ & Delivery & Disease \\
\hline 03638167 & Phase I & $\begin{array}{l}\text { EGFR806-specific CAR } \\
\text { T Cell Locoregional } \\
\text { Immunotherapy for } \\
\text { EGFR-positive } \\
\text { Recurrent or Refractory } \\
\text { Pediatric Central } \\
\text { Nervous System Tumors }\end{array}$ & $\begin{array}{l}\text { Seattle } \\
\text { Children's } \\
\text { Hospital }\end{array}$ & EGFR & & IT, IC & $\begin{array}{l}\text { Pediatric Glioma, } \\
\text { Ependymoma, } \\
\text { Medulloblastoma, Germ } \\
\text { Cell Tumor, ATRT, PNET, } \\
\text { Choroid Plexus Carcinoma, } \\
\text { Pineoblastoma }\end{array}$ \\
\hline 03500991 & Phase I & $\begin{array}{l}\text { HER2-Specific CAR } \\
\text { T Cell Locoregional } \\
\text { Immunotherapy for } \\
\text { HER2 Positive } \\
\text { Recurrent/Refractory } \\
\text { Pediatric Central } \\
\text { Nervous System Tumors }\end{array}$ & $\begin{array}{l}\text { Seattle } \\
\text { Children's } \\
\text { Hospital }\end{array}$ & HER2 & & IT, IC & $\begin{array}{l}\text { Pediatric Glioma, } \\
\text { Ependymoma, } \\
\text { Medulloblastoma, Germ } \\
\text { Cell Tumor, ATRT, PNET, } \\
\text { Choroid Plexus Carcinoma, } \\
\text { Pineoblastoma }\end{array}$ \\
\hline 02442297 & Phase I & $\begin{array}{l}\text { Intracranial Injection of T } \\
\text { Cells Expressing } \\
\text { HER2-specific Chimeric } \\
\text { Antigen Receptors } \\
\text { (CAR) in Subjects With } \\
\text { HER2-Positive Tumors } \\
\text { of the Central Nervous } \\
\text { System (iCAR) }\end{array}$ & $\begin{array}{l}\text { Texas } \\
\text { Children's } \\
\text { Hospital }\end{array}$ & HER2 & & IT, IC & $\begin{array}{l}\text { Brain Tumor, Recurrent } \\
\text { Brain Tumor, Refractory } \\
\text { Excludes DIPG/DMG }\end{array}$ \\
\hline
\end{tabular}

Table data accrued July 19, 2020 from ClinicalTrials.gov.

While little is known about the differences between tumor immune microenvironments in pedatric versus adult gliomas, some studies have shown that pDMGs show unique properties (156). In contrast to pNMGs, pDMGs do not have increased $\mathrm{T}$ cell infiltration compared to adjacent non-tumor infiltrated brain and appears to not have an inflammatory cytokine profile (157). Sequencing of macrophages from tissue samples in both pDMGs and adult GBM have shown that both express genetic changes related to extracellular matrix remodeling and angiogenesis. However, pDMG-associated macrophages express less inflammatory factors than adult GBM macrophages (158). Thus, the lack of T-cell invasion and overall low inflammatory environment could potentially make pDMGs excellent candidates for CAR-T cells as the microenvironment is less immunosuppressive relative to adult tumor counterparts $(158,159)$.

\section{TREATMENT TOXICITY AND RISKS}

CAR $\mathrm{T}$ cell therapy can lead to treatment associated toxicity. Cytokine release syndrome (CRS) is one of the most common and severe toxicities associated with CAR $\mathrm{T}$ cell therapy results from systemic immune activation. While elevation of inflammatory cytokines is expected, and often produces mild flu-like symptoms, multiorgan system failure and death has been reported from CRS (160). The most elevated cytokines typically seen are IL-10, IL-6, and IFN- $\gamma$. CRS can be managed with the use of corticosteroids and interleukin- 6 blockade (161, 162). Corticosteroids can have a negative impact on T-cell proliferation and therefore clinicians may consider other forms of CRS management. Out of the 3 cytokines involved, regulation of IL-6 should produce both desired control of CRS without downregulation of desired immune function (163). IL-6 blockade 
via tocilizumab has shown dramatic reversal of severe CRS in patients treated with CART-19, and thus is actively being studied in other therapies $(164,165)$. Another method managing severe CRS is engineering suicide genes into the CAR-T cells. With a suicide gene/switch in place, administration of an antibody or small molecule can induce apoptosis of CAR-T cells to prevent further immune stimulation and reverse CRS (166-168).

Despite the availability of multiple treatment modalities, CRS can still be deadly and needs to be recognized early (169). Neurotoxicity is another complication which has recently been termed immune effector cell-associated neurotoxicity syndrome (ICANS). ICANS is the second most common adverse event following CAR T-cell infusion. ICANS has a wide spectrum of symptoms and can range from mild confusion to being in a comatose state (170). Similar to CRS, ICANS can be deadly and therefore any neurological symptom occurring after CAR T cell infusion must be considered potential ICANS until proven otherwise. In a meta-analysis of CAR T cell trials for cancer, 55.3 and $37.2 \%$ of all patients experienced CRS and neurotoxicity, respectively (171).

Intrathecal or locoregional infusion of CAR $\mathrm{T}$ cells for brain tumor therapy may mitigate these toxicities experienced following intravenous administration (Figure 1). Intrathecal therapy is a passive form of delivery and normal CSF flow is required for adequate dissemination throughout the CNS. Furthermore, this modality may not penetrate bulky disease sites (172). These are clinical considerations to account for when choosing a delivery method. One other particular concern in regards to pediatric brain tumors is the prediliction for tumors in the posterior fossa or along the ventricular pathway. In preclinical models, expected treatment related inflammation following CAR T cell therapy can cause brain swelling which can lead to hydrocephalus (137). Hydrocephalus can be morbid and require urgent CSF diversion. These risks may occur more frequently as the clinical experience expands in pediatric brain tumors.

\section{DISCUSSION AND FUTURE DIRECTIONS}

Overall, current clinical trials using CAR-T cells for pediatric brain tumors are in early stages (Table 2 ). The antigenic targets of these trials have been discussed in previous sections and are summarized in Table 1. Five clinical trials are currently recruiting pediatric patients, however, results will likely be slow to report due to the combined rarity and mortality of these tumors. However, CAR-T therapy in xenograft models continues to provide hope in reaching long-term disease free survival.

The first in-human studies of CAR-T cells for GBM was administered through intravenous delivery. O'Rourke et al. demonstrated that with while all patients had detectable transient expansion of EGFRvIII CAR-T cell in peripheral blood, not all patients had significant signs of trafficking and intra-tumor effects (173). Ahmed et al. showed a dramatic response in an adolescent patient, and stable disease in 7 others after HER2 CAR-T infusion (132). Brown et al. was among the first to show regression of GBM in a patient after intratumor and intraventricular infusion of IL13R $\alpha 2$ CAR-T cells (145). Route of administration that optimizes efficacy will be a main factor to delineate in future trials.

Assessing response to immunotherapy remains another hurdle to overcome in the context of CNS cancer. The standard of care in monitoring tumor progression and response is magnetic resonance imaging, but, pseudo-progression after immunotherapy can make interpretation of imaging difficult. Pseudo-progression and immune related edema is an expected result of targeting and stimulating the immune system, and more advanced imaging analysis stratagies are underway in helping to differentiate between true progression of disease (174-176). Despite these concerns, multiple clinical trials have shown that patients still achieve meaningful clinical response despite early pseudo-progression findings (174, 177-181).

Currently, trials are targeting cell surface antigens on cancer cells but scFv targeting epitope/HLA complex makes it possible for intracellular proteins to be candidate targets (182). This technology will be a significant game changer allowing for clinicians to target intracellular oncogenic pathways. Besides targeting cancer cells, considerations of how to target the microenvironment to enhance anti-tumor activity is underway (183). In pediatric brain tumors, further work is needed to delinate the tumor microenvironment taking into account subtype variability. With the advent of immunomodulatory agents such as checkpoint inhibition, multimodal immunotherapy can also be considered for patients (184). Lastly, the application of CAR engineering to other immune effector cells such as NK cells opens another avenue of potential innovation (185).

\section{CONCLUSION}

There has been critical advancements in the last decade that have allowed for the development of CAR T cells for brain tumors. The prognosis for many pediatric brain tumors remains dismal and there is promise in CAR T cell therapy. Continued preclinical research is needed to address our current gaps such as identifying the best mode of delivery, defining the microenvironment, developing new targets and increasing efficacy. Despite these challenges the future of CAR T cells for pediatric brain tumor management is bright.

\section{AUTHOR CONTRIBUTIONS}

JP: methodology, data curation, and writing - original draft, review, and editing. JH: writing - original draft. RB: figure construction. KB: supervision and writing - review and editing. AR: conceptualization, resources, supervision, and writing review and editing. All authors contributed to the article and approved the submitted version.

\section{FUNDING}

This work was supported by the NIH Grant P20GM109005. 


\section{REFERENCES}

1. Rodriguez A, Brown C, Badie B. Chimeric antigen receptor T-cell therapy for glioblastoma. Transl Res. (2017) 187:93-102. doi: 10.1016/j.trsl.2017.07.003

2. Mirzaei HR, Rodriguez A, Shepphird J, Brown CE, Badie B. Chimeric antigen receptors $\mathrm{T}$ cell therapy in solid tumor: challenges and clinical applications. Front Immunol. (2017) 8:1850. doi: 10.3389/fimmu.2017.01850

3. Donovan LK, Delaidelli A, Joseph SK, Bielamowicz K, Fousek K, Holgado $\mathrm{BL}$, et al. Locoregional delivery of CAR $\mathrm{T}$ cells to the cerebrospinal fluid for treatment of metastatic medulloblastoma and ependymoma. Nat Med. (2020) 26:720-31. doi: 10.1038/s41591-020-0827-2

4. Withrow DR, De Gonzalez AB, Lam CJK, Warren KE, Shiels MS. Trends in pediatric central nervous system tumor incidence in the United States, 1998-2013. Cancer Epidemiol Biomarkers Prev. (2019) 28:522-30. doi: 10. 1158/1055-9965.EPI-18-0784

5. Gross G, Waks T, Eshhar Z. Expression of immunoglobulin-T-cell receptor chimeric molecules as functional receptors with antibody-type specificity. Proc Natl Acad Sci USA. (1989) 86:10024-8. doi: 10.1073/pnas.86.24.10024

6. Eshhar Z, Waks T, Gross G, Schindler DG. Specific activation and targeting of cytotoxic lymphocytes through chimeric single chains consisting of antibodybinding domains and the gamma or zeta subunits of the immunoglobulin and T-cell receptors. Proc Natl Acad Sci USA. (1993) 90:720-4. doi: 10.1073/pnas. 90.2.720

7. Gaudino SJ, Kumar P. Cross-talk between antigen presenting cells and T cells impacts intestinal homeostasis, bacterial infections, and tumorigenesis. Front Immunol. (2019) 10:360. doi: 10.3389/fimmu.2019.00360

8. Finney HM, Lawson AD, Bebbington CR, Weir AN. Chimeric receptors providing both primary and costimulatory signaling in $\mathrm{T}$ cells from a single gene product. J Immunol. (1998) 161:2791-7.

9. Tammana S, Huang X, Wong M, Milone MC, Ma L, Levine BL, et al. 4$1 \mathrm{BB}$ and $\mathrm{CD} 28$ signaling plays a synergistic role in redirecting umbilical cord blood T Cells against B-cell malignancies. Hum Gene Ther. (2010) 21:75-86. doi: 10.1089/hum.2009.122

10. van der Stegen SJC, Hamieh M, Sadelain M. The pharmacology of secondgeneration chimeric antigen receptors. Nat Rev Drug Discov. (2015) 14:499509. doi: $10.1038 / \mathrm{nrd} 4597$

11. Fournier C, Martin F, Zitvogel L, Kroemer G, Galluzzi L, Apetoh L. Trial Watch: adoptively transferred cells for anticancer immunotherapy. Oncoimmunology. (2017) 6:e1363139. doi: 10.1080/2162402X.2017.1363139

12. Yang X, Wang GX, Feng ZJ. CAR T cell therapy for hematological malignancies. Curr Med Sci. (2019) 39:874-82. doi: 10.1007/s11596-0192118-z

13. Ma S, Li X, Wang X, Cheng L, Li Z, Zhang C, et al. Current progress in car-t cell therapy for solid tumors. Int J Biol Sci. (2019) 15:2548-60. doi: $10.7150 /$ ijbs. 34213

14. Abbott NJ. Blood-brain barrier structure and function and the challenges for CNS drug delivery. J Inherit Metab Dis. (2013) 36:437-49. doi: 10.1007/ s10545-013-9608-0

15. Arvanitis CD, Ferraro GB, Jain RK. The blood-brain barrier and bloodtumour barrier in brain tumours and metastases. Nat Rev Cancer. (2020) 20:26-41. doi: 10.1038/s41568-019-0205-x

16. Akhavan D, Alizadeh D, Wang D, Weist MR, Shepphird JK, Brown CE. CAR $\mathrm{T}$ cells for brain tumors: lessons learned and road ahead. Immunol Rev. (2019) 290:60-84. doi: 10.1111/imr.12773

17. Smoll NR, Drummond KJ. The incidence of medulloblastomas and primitive neurectodermal tumours in adults and children. J Clin Neurosci. (2012) 19:1541-4. doi: 10.1016/j.jocn.2012.04.009

18. Packer RJ, Rood BR, MacDonald TJ. Medulloblastoma: Present concepts of stratification into risk groups. Pediatr Neurosurg. (2003) 39:60-7. doi: $10.1159 / 000071316$

19. Taylor MD, Northcott PA, Korshunov A, Remke M, Cho Y-J, Clifford SC, et al. Molecular subgroups of medulloblastoma: the current consensus. Acta Neuropathol. (2012) 123:465-72. doi: 10.1007/s00401-011-0922-z

20. Roussel MF, Hatten ME. Cerebellum: development and medulloblastoma. Curr Top Dev Biol. (2011) 94:235-82. doi: 10.1016/B978-0-12-380916-2. 00008-5

21. Lu VM, Pendleton C, Brown DA, Lakomkin N, Cho S, Miller KJ, et al. Shaping our understanding of medulloblastoma: a bibliometric analysis of the 100 most cited articles. Clin Neurol Neurosurg. (2020) 194:105895. doi: 10.1016/j.clineuro.2020.105895

22. Taylor RE, Bailey CC, Robinson KJ, Weston CL, Walker DA, Ellison D, et al. Outcome for patients with metastatic (M2-3) medulloblastoma treated with SIOP/UKCCSG PNET-3 chemotherapy. Eur J Cancer. (2005) 41:727-34. doi: 10.1016/j.ejca.2004.12.017

23. Tarbell NJ, Friedman H, Polkinghorn WR, Yock T, Zhou T, Chen Z, et al. High-risk medulloblastoma: a pediatric oncology group randomized trial of chemotherapy before or after radiation therapy (POG 9031). J Clin Oncol. (2013) 31:2936-41. doi: 10.1200/JCO.2012.43.9984

24. Packer RJ, Gajjar A, Vezina G, Rorke-Adams L, Burger PC, Robertson PL, et al. Phase III study of craniospinal radiation therapy followed by adjuvant chemotherapy for newly diagnosed average-risk medulloblastoma. J Clin Oncol. (2006) 24:4202-8. doi: 10.1200/JCO.2006.06.4980

25. Gandola L, Massimino M, Cefalo G, Solero C, Spreafico F, Pecori E, et al. Hyperfractionated accelerated radiotherapy in the milan strategy for metastatic medulloblastoma. J Clin Oncol. (2009) 27:566-71. doi: 10.1200/ JCO.2008.18.4176

26. Lannering B, Rutkowski S, Doz F, Pizer B, Gustafsson G, Navajas A, et al. Hyperfractionated versus conventional radiotherapy followed by chemotherapy in standard-risk medulloblastoma: results from the randomized multicenter HIT-SIOP PNET 4 Trial. J Clin Oncol. (2012) 30:3187-93. doi: 10.1200/JCO.2011.39.8719

27. Ramaswamy V, Remke M, Bouffet E, Bailey S, Clifford SC, Doz F, et al. Risk stratification of childhood medulloblastoma in the molecular era: the current consensus. Acta Neuropathol. (2016) 131:821-31. doi: 10.1007/s00401-0161569-6

28. Sayour EJ, Mitchell DA. Immunotherapy for Pediatric Brain Tumors. Brain Sci. (2017) 7:137. doi: 10.3390/brainsci7100137

29. Ellison DW, Kocak M, Dalton J, Megahed H, Lusher ME, Ryan SL, et al. Definition of disease-risk stratification groups in childhood medulloblastoma using combined clinical, pathologic, and molecular variables. J Clin Oncol. (2011) 29:1400-7. doi: 10.1200/JCO.2010.30.2810

30. Zurawel RH, Chiappa SA, Allen C, Raffel C. Sporadic medulloblastomas contain oncogenic beta-catenin mutations. Cancer Res. (1998) 58:896-9.

31. Hamilton SR, Liu B, Parsons RE, Papadopoulos N, Jen J, Powell SM, et al. The molecular basis of turcot's syndrome. N Engl J Med. (1995) 332:839-47. doi: 10.1056/NEJM199503303321302

32. Pastorino L, Ghiorzo P, Nasti S, Battistuzzi L, Cusano R, Marzocchi C, et al. Identification of a SUFU germline mutation in a family with Gorlin syndrome. Am J Med Genet A. (2009) 149A:1539-43. doi: 10.1002/ajmg.a. 32944

33. Bale SJ, Falk RT, Rogers GR. Patching together the genetics of Gorlin syndrome. J Cutan Med Surg. (1998) 3:31-4. doi: 10.1177/ 120347549800300109

34. Taylor MD, Liu L, Raffel C, Hui C, Mainprize TG, Zhang X, et al. Mutations in SUFU predispose to medulloblastoma. Nat Genet. (2002) 31:306-10. doi: $10.1038 /$ ng916

35. Slade I, Murray A, Hanks S, Kumar A, Walker L, Hargrave D, et al. Heterogeneity of familial medulloblastoma and contribution of germline PTCH1 and SUFU mutations to sporadic medulloblastoma. Fam Cancer. (2011) 10:337-42. doi: 10.1007/s10689-010-9411-0

36. Brugières L, Pierron G, Chompret A, Paillerets BB, Di Rocco F, Varlet P, et al. Incomplete penetrance of the predisposition to medulloblastoma associated with germ-line SUFU mutations. J Med Genet. (2010) 47:142-4. doi: 10.1136/ jmg.2009.067751

37. Northcott PA, Hielscher T, Dubuc A, Mack S, Shih D, Remke M, et al. Pediatric and adult sonic hedgehog medulloblastomas are clinically and molecularly distinct. Acta Neuropathol. (2011) 122:231-40. doi: 10.1007/ s00401-011-0846-7

38. Northcott PA, Nakahara Y, Wu X, Feuk L, Ellison DW, Croul S, et al. Multiple recurrent genetic events converge on control of histone lysine methylation in medulloblastoma. Nat Genet. (2009) 41:465-72. doi: 10.1038/ ng. 336

39. Zhukova N, Ramaswamy V, Remke M, Pfaff E, Shih DJH, Martin DC, et al. Subgroup-specific prognostic implications of TP53 mutation in medulloblastoma. J Clin Oncol. (2013) 31:2927-35. doi: 10.1200/JCO.2012. 48.5052 
40. Kool M, Koster J, Bunt J, Hasselt NE, Lakeman A, van Sluis P, et al. Integrated genomics identifies five medulloblastoma subtypes with distinct genetic profiles, pathway signatures and clinicopathological features. PLoS One. (2008) 3:e3088. doi: 10.1371/journal.pone.0003088

41. Northcott PA, Korshunov A, Witt H, Hielscher T, Eberhart CG, Mack S, et al. Medulloblastoma comprises four distinct molecular variants. J Clin Oncol. (2011) 29:1408-14. doi: 10.1200/JCO.2009.27.4324

42. Cho Y-J, Tsherniak A, Tamayo P, Santagata S, Ligon A, Greulich H, et al. Integrative genomic analysis of medulloblastoma identifies a molecular subgroup that drives poor clinical outcome. J Clin Oncol. (2011) 29:1424-30. doi: $10.1200 /$ JCO.2010.28.5148

43. Di C, Liao S, Adamson DC, Parrett TJ, Broderick DK, Shi Q, et al. Identification of OTX2 as a medulloblastoma oncogene whose product can be targeted by all-trans retinoic acid. Cancer Res. (2005) 65:919-24.

44. De Haas T, Oussoren E, Grajkowska W, Perek-Polnik M, Popovic M, Zadravec-Zaletel L, et al. OTX1 and OTX2 expression correlates with the clinicopathologic classification of medulloblastomas. J Neuropathol Exp Neurol. (2006) 65:176-86. doi: 10.1097/01.jnen.0000199576.70923.8a

45. Adamson DC, Shi Q, Wortham M, Northcott PA, Di C, Duncan CG, et al. OTX2 is critical for the maintenance and progression of shh-independent medulloblastomas. Cancer Res. (2010) 70:181-91. doi: 10.1158/0008-5472. CAN-09-2331

46. Kool M, Korshunov A, Remke M, Jones DTW, Schlanstein M, Northcott PA, et al. Molecular subgroups of medulloblastoma: an international metaanalysis of transcriptome, genetic aberrations, and clinical data of WNT, SHH, Group 3, and Group 4 medulloblastomas. Acta Neuropathol. (2012) 123:473-84. doi: 10.1007/s00401-012-0958-8

47. Orentas RJ, Lee DW, Mackall C. Immunotherapy targets in pediatric cancer. Front Oncol. (2012) 2:3. doi: 10.3389/fonc.2012.00003

48. Uhlén M, Fagerberg L, Hallström BM, Lindskog C, Oksvold P, Mardinoglu A, et al. Proteomics. Tissue-based map of the human proteome. Science. (2015) 347:1260419. doi: 10.1126/science.1260419

49. Ahmed N, Ratnayake M, Savoldo B, Perlaky L, Dotti G, Wels WS, et al. Regression of experimental medulloblastoma following transfer of HER2specific T cells. Cancer Res. (2007) 67:5957-64. doi: 10.1158/0008-5472. CAN-06-4309

50. Nellan A, Rota C, Majzner R, Lester-McCully CM, Griesinger AM, Mulcahy Levy JM, et al. Durable regression of Medulloblastoma after regional and intravenous delivery of anti-HER2 chimeric antigen receptor T cells. $J$ Immunother Cancer. (2018) 6:30. doi: 10.1186/s40425-018-0340-z

51. Long AH, Haso WM, Shern JF, Wanhainen KM, Murgai M, Ingaramo M, et al. 4-1BB costimulation ameliorates $\mathrm{T}$ cell exhaustion induced by tonic signaling of chimeric antigen receptors. Nat Med. (2015) 21:581-90. doi: 10.1038/nm.3838

52. Zhang Z, Jiang C, Liu Z, Yang M, Tang X, Wang Y, et al. B7-H3-targeted CAR$\mathrm{T}$ cells exhibit potent antitumor effects on hematologic and solid tumors. Mol Ther Oncolytics. (2020) 17:180-9. doi: 10.1016/j.omto.2020.03.019

53. Majzner RG, Theruvath JL, Nellan A, Heitzeneder S, Cui Y, Mount CW, et al. CAR T cells targeting B7-H3, a Pan-cancer antigen, demonstrate potent preclinical activity against pediatric solid tumors and brain tumors. Clin Cancer Res. (2019) 25:2560-74. doi: 10.1158/1078-0432.CCR-18-0432

54. Bielamowicz K, Fousek K, Byrd TT, Samaha H, Mukherjee M, Aware N, et al. Trivalent CAR $\mathrm{T}$ cells overcome interpatient antigenic variability in glioblastoma. Neuro Oncol. (2018) 20:506-18. doi: 10.1093/neuonc/ nox182

55. Fratta E, Coral S, Covre A, Parisi G, Colizzi F, Danielli R, et al. The biology of cancer testis antigens: putative function, regulation and therapeutic potential. Mol Oncol. (2011) 5:164-82. doi: 10.1016/j.molonc.2011.02.001

56. Orlando D, Miele E, De Angelis B, Guercio M, Boffa I, Sinibaldi $\mathrm{M}$, et al. Adoptive immunotherapy using PRAME-specific $\mathrm{T}$ cells in medulloblastoma. Cancer Res. (2018) 78:canres.3140.2017. doi: 10.1158/ 0008-5472.CAN-17-3140

57. González-Galarza FF, Takeshita LYC, Santos EJM, Kempson F, Maia MHT, Silva ALS, et al. Allele frequency net 2015 update: new features for HLA epitopes, KIR and disease and HLA adverse drug reaction associations. Nucleic Acids Res. (2015) 43:D784-8. doi: 10.1093/nar/gku1166

58. Riaz N, Havel JJ, Makarov V, Horak CE, Weinhold N, Chan TA. Tumor and microenvironment evolution during immunotherapy with nivolumab. Cell. (2017) 171:934-49.e16. doi: 10.1016/j.cell.2017.09.028 doi: 10.1016/j.cell.2017.09.028

59. Cheng J, Zhao L, Zhang Y, Qin Y, Guan Y, Zhang T, et al. Understanding the mechanisms of resistance to CAR T-cell therapy in malignancies. Front Oncol. (2019) 9:1237. doi: 10.3389/fonc.2019.01237

60. Haberthur K, Brennan K, Hoglund V, Balcaitis S, Chinn H, Davis A, et al. NKG2D ligand expression in pediatric brain tumors. Cancer Biol Ther. (2016) 17:1253-65. doi: 10.1080/15384047.2016.1250047

61. Margol AS, Robison NJ, Gnanachandran J, Hung LT, Kennedy RJ, Vali M, et al. Tumor-associated macrophages in SHH subgroup of medulloblastomas. Clin Cancer Res. (2015) 21:1457-65. doi: 10.1158/1078-0432.CCR-14- 1144

62. Pham CD, Flores C, Yang C, Pinheiro EM, Yearley JH, Sayour EJ, et al. Differential immune microenvironments and response to immune checkpoint blockade among molecular subtypes of murine medulloblastoma. Clin Cancer Res. (2016) 22:582-95. doi: 10.1158/1078-0432.CCR-15-0713

63. Pham CD, Mitchell DA. Know your neighbors: Different tumor microenvironments have implications in immunotherapeutic targeting strategies across MB subgroups. Oncoimmunology. (2016) 5:e1144002. doi: 10.1080/2162402X.2016.1144002

64. Vermeulen JF, Van Hecke W, Adriaansen EJM, Jansen MK, Bouma RG, Villacorta Hidalgo J, et al. Prognostic relevance of tumor-infiltrating lymphocytes and immune checkpoints in pediatric medulloblastoma. Oncoimmunology. (2018) 7:e1398877. doi: 10.1080/2162402X.2017.1398877

65. Majzner RG, Simon JS, Grosso JF, Martinez D, Pawel BR, Santi M, et al. Assessment of programmed death-ligand 1 expression and tumor-associated immune cells in pediatric cancer tissues. Cancer. (2017) 123:3807-15. doi: $10.1002 /$ cncr. 30724

66. Murata D, Mineharu Y, Arakawa Y, Liu B, Tanji M, Yamaguchi M, et al. High programmed cell death 1 ligand-1 expression: association with CD8+ T-cell infiltration and poor prognosis in human medulloblastoma. J Neurosurg. (2018) 128:710-6. doi: 10.3171/2016.11.JNS16991

67. Bockmayr M, Mohme M, Klauschen F, Winkler B, Budczies J, Rutkowski $\mathrm{S}$, et al. Subgroup-specific immune and stromal microenvironment in medulloblastoma. Oncoimmunology. (2018) 7:e1462430. doi: 10.1080/ 2162402X.2018.1462430

68. Korshunov A, Witt H, Hielscher T, Benner A, Remke M, Ryzhova M, et al. Molecular staging of intracranial ependymoma in children and adults. J Clin Oncol. (2010) 28:3182-90. doi: 10.1200/JCO.2009.27.3359

69. Ostrom QT, Gittleman H, Truitt G, Boscia A, Kruchko C, Barnholtz-Sloan JS. CBTRUS statistical report: primary brain and other central nervous system tumors diagnosed in the United States in 2011-2015. Neuro Oncol. (2018) 20:iv1-86. doi: 10.1093/neuonc/noy131

70. Louis DN, Perry A, Reifenberger G, von Deimling A, Figarella-Branger D, Cavenee WK, et al. The 2016 world health organization classification of tumors of the central nervous system: a summary. Acta Neuropathol. (2016) 131:803-20. doi: 10.1007/s00401-016-1545-1

71. Merchant TE, Bendel AE, Sabin ND, Burger PC, Shaw DW, Chang E, et al. Conformal radiation therapy for pediatric ependymoma, chemotherapy for incompletely resected ependymoma, and observation for completely resected, supratentorial ependymoma. J Clin Oncol. (2019) 37:974-83. doi: 10.1200/JCO.18.01765

72. Merchant TE, Li C, Xiong X, Kun LE, Boop F. Sanford. A prospective study of conformal radiation therapy for pediatric ependymoma. Lancet Oncol. (2009) 10:258-66. doi: 10.1016/S1470-2045(08)70342-5.A

73. Tsang DS, Burghen E, Klimo P, Boop FA, Ellison DW, Merchant TE. Outcomes after reirradiation for recurrent pediatric intracranial ependymoma. Int J Radiat Oncol Biol Phys. (2018) 100:507-15. doi: 10.1016/ j.ijrobp.2017.10.002

74. Upadhyaya SA, Robinson GW, Onar-Thomas A, Orr BA, Billups CA, Bowers DC, et al. Molecular grouping and outcomes of young children with newly diagnosed ependymoma treated on the multi-institutional SJYC07 trial. Neuro Oncol. (2019) 21:1319-30. doi: 10.1093/neuonc/noz069

75. Zapotocky M, Beera K, Adamski J, Laperierre N, Guger S, Janzen L, et al. Survival and functional outcomes of molecularly defined childhood posterior fossa ependymoma: cure at a cost. Cancer. (2019) 125:1867-76. doi: 10.1002/ cncr.31995

76. Pajtler KW, Witt H, Sill M, Jones DTW, Hovestadt V, Kratochwil F, et al. Molecular classification of ependymal tumors across all CNS compartments, 
histopathological grades, and age groups. Cancer Cell. (2015) 27:728-43. doi: 10.1016/j.ccell.2015.04.002

77. Yeung JT, Hamilton RL, Okada H, Jakacki RI, Pollack IF. Increased expression of tumor-associated antigens in pediatric and adult ependymomas: implication for vaccine therapy. J Neurooncol. (2013) 111:103-11. doi: 10.1007/s11060-012-0998-x

78. Zhang JG, Kruse CA, Driggers L, Hoa N, Wisoff J, Allen JC, et al. Tumor antigen precursor protein profiles of adult and pediatric brain tumors identify potential targets for immunotherapy. J Neurooncol. (2008) 88:65-76. doi: 10.1007/s11060-008-9534-4

79. Witt H, Mack SC, Ryzhova M, Bender S, Sill M, Isserlin R, et al. Delineation of two clinically and molecularly distinct subgroups of posterior fossa ependymoma. Cancer Cell. (2011) 20:143-57. doi: 10.1016/j.ccr.2011.07.007

80. Griesinger AM, Josephson RJ, Donson AM, Levy JMM, Amani V, Birks DK, et al. Interleukin-6/STAT3 pathway signaling drives an inflammatory phenotype in group a ependymoma. Cancer Immunol Res. (2015) 3:1165-74. doi: 10.1158/2326-6066.CIR-15-0061

81. Witt DA, Donson AM, Amani V, Moreira DC, Sanford B, Hoffman LM, et al. Specific expression of PD-L1 in RELA-fusion supratentorial ependymoma: implications for PD-1-targeted therapy. Pediatr Blood Cancer. (2018) 65:e26960. doi: 10.1002/pbc.26960

82. Griesinger AM, Birks DK, Donson AM, Amani V, Hoffman LM, Waziri A, et al. Characterization of distinct immunophenotypes across pediatric brain tumor types. J Immunol. (2013) 191:4880-8. doi: 10.4049/jimmunol.1301966

83. Hoffman LM, Donson AM, Nakachi I, Griesinger AM, Birks DK, Amani $\mathrm{V}$, et al. Molecular sub-group-specific immunophenotypic changes are associated with outcome in recurrent posterior fossa ependymoma. Acta Neuropathol. (2014) 127:731-45. doi: 10.1007/s00401-013-1212-8

84. Buscariollo DL, Park HS, Roberts KB, Yu JB. Survival outcomes in atypical teratoid rhabdoid tumor for patients undergoing radiotherapy in a Surveillance, Epidemiology, and End Results analysis. Cancer. (2012) 118:4212-9. doi: 10.1002/cncr.27373

85. Lafay-Cousin L, Hawkins C, Carret AS, Johnston D, Zelcer S, Wilson B, et al. Central nervous system atypical teratoid rhabdoid tumours: the canadian paediatric brain tumour consortium experience. Eur J Cancer. (2012) 48:3539. doi: 10.1016/j.ejca.2011.09.005

86. Dufour C, Beaugrand A, Le Deley MC, Bourdeaut F, André N, Leblond P, et al. Clinicopathologic prognostic factors in childhood atypical teratoid and rhabdoid tumor of the central nervous system: a multicenter study. Cancer. (2012) 118:3812-21. doi: 10.1002/cncr.26684

87. Zaky W, Dhall G, Ji L, Haley K, Allen J, Atlas M, et al. Intensive induction chemotherapy followed by myeloablative chemotherapy with autologous hematopoietic progenitor cell rescue for young children newly-diagnosed with central nervous system atypical teratoid/rhabdoid tumors: the head start III experience. Pediatr Blood Cancer. (2014) 61:95-101. doi: 10.1002/pbc. 24648

88. Chi SN, Zimmerman MA, Yao X, Cohen KJ, Burger P, Biegel JA, et al. Intensive multimodality treatment for children with newly diagnosed CNS atypical teratoid rhabdoid tumor. J Clin Oncol. (2009) 27:385-9. doi: 10.1200/ JCO.2008.18.7724

89. Nicolaides T, Tihan T, Horn B, Biegel J, Prados M, Banerjee A. High-dose chemotherapy and autologous stem cell rescue for atypical teratoid/rhabdoid tumor of the central nervous system. J Neurooncol. (2010) 98:117-23. doi: 10.1007/s11060-009-0071-6

90. Reddy AT, Strother DR, Judkins AR, Burger PC, Pollack IF, Krailo MD, et al. Efficacy of high-dose chemotherapy and three-dimensional conformal radiation for atypical teratoid/rhabdoid tumor: a report from the children's oncology group trial ACNS0333. J Clin Oncol. (2020) 38:1175-85. doi: 10. 1200/JCO.19.01776

91. Biswas A, Kashyap L, Kakkar A, Sarkar C, Julka PK. Atypical teratoid/rhabdoid tumors: challenges and search for solutions. Cancer Manag Res. (2016) 8:115-25. doi: 10.2147/CMAR.S83472

92. Torchia J, Golbourn B, Feng S, Ho KC, Sin-Chan P, Vasiljevic A, et al. Integrated (epi)-genomic analyses identify subgroup-specific therapeutic targets in CNS rhabdoid tumors. Cancer Cell. (2016) 30:891-908. doi: 10. 1016/j.ccell.2016.11.003

93. Kram D, Henderson J, Baig M, Chakraborty D, Gardner M, Biswas S, et al. Embryonal tumors of the central nervous system in children: the era of targeted therapeutics. Bioengineering. (2018) 5:78. doi: 10.3390/ bioengineering 5040078

94. Torchia J, Picard D, Lafay-Cousin L, Hawkins CE, Kim SK, Letourneau L, et al. Molecular subgroups of atypical teratoid rhabdoid tumours in children: an integrated genomic and clinicopathological analysis. Lancet Oncol. (2015) 16:569-82. doi: 10.1016/S1470-2045(15)70114-2

95. Coccé MC, Lubieniecki F, Kordes U, Alderete D, Gallego MS. A complex karyotype in an atypical teratoid/rhabdoid tumor: case report and review of the literature. J Neurooncol. (2011) 104:375-80. doi: 10.1007/s11060-0100478-0

96. Johann PD, Erkek S, Zapatka M, Kerl K, Buchhalter I, Hovestadt V, et al. Atypical teratoid/rhabdoid tumors are comprised of three epigenetic subgroups with distinct enhancer landscapes. Cancer Cell. (2016) 29:379-93. doi: $10.1016 /$ j.ccell.2016.02.001

97. Batlle E, Clevers H. Cancer stem cells revisited. Nat Med. (2017) 23:1124-34. doi: 10.1038/nm.4409

98. Golan H, Shukrun R, Caspi R, Vax E, Pode-Shakked N, Goldberg S, et al. In vivo expansion of cancer stemness affords novel cancer stem cell targets: malignant rhabdoid tumor as an example. Stem Cell Rep. (2018) 11:795-810. doi: 10.1016/j.stemcr.2018.07.010

99. Qi Y, Zhao W, Li M, Shao M, Wang J, Sui H, et al. High C-X-C motif chemokine 5 expression is associated with malignant phenotypes of prostate cancer cells via autocrine and paracrine pathways. Int J Oncol. (2018) 53:35870. doi: $10.3892 /$ ijo. 2018.4388

100. Gijsbers K, Gouwy M, Struyf S, Wuyts A, Proost P, Opdenakker G, et al. GCP-2/CXCL6 synergizes with other endothelial cell-derived chemokines in neutrophil mobilization and is associated with angiogenesis in gastrointestinal tumors. Exp Cell Res. (2005) 303:331-42. doi: 10.1016/j. yexcr.2004.09.027

101. Linge HM, Collin M, Nordenfelt P, Mörgelin M, Malmsten M, Egesten A. The human CXC chemokine granulocyte chemotactic protein 2 (GCP-2)/CXCL6 possesses membrane-disrupting properties and is antibacterial. Antimicrob Agents Chemother. (2008) 52:2599-607. doi: 10.1128/AAC.00028-08

102. Schmidt T, Samaras P, Frejno M, Gessulat S, Barnert M, Kienegger H, et al. ProteomicsDB. Nucleic Acids Res. (2018) 46:D1271-81. doi: 10.1093/nar/ gkx1029

103. Wilhelm M, Schlegl J, Hahne H, Gholami AM, Lieberenz M, Savitski MM, et al. Mass-spectrometry-based draft of the human proteome. Nature. (2014) 509:582-7. doi: 10.1038/nature13319

104. Katoh M. Antibody-drug conjugate targeting protein tyrosine kinase 7, a receptor tyrosine kinase-like molecule involved in WNT and vascular endothelial growth factor signaling: effects on cancer stem cells, tumor microenvironment and whole-body homeostasis. Ann Transl Med. (2017) 5:462. doi: $10.21037 / \mathrm{atm} .2017 .09 .11$

105. Messerli SM, Hoffman MM, Gnimpieba EZ, Bhardwaj RD. Therapeutic targeting of PTK7 is cytotoxic in atypical teratoid rhabdoid tumors. Mol Cancer Res. (2017) 15:973-83. doi: 10.1158/1541-7786.MCR-16-0432

106. Damelin M, Bankovich A, Bernstein J, Lucas J, Chen L, Williams S, et al. A PTK7-targeted antibody-drug conjugate reduces tumor-initiating cells and induces sustained tumor regressions. Sci Transl Med. (2017) 9:eaag2611. doi: 10.1126/scitranslmed.aag2611

107. Yang YP, Nguyen PNN, Ma HI, Ho WJ, Chen YW, Chien Y, et al. Tumor mesenchymal stromal cells regulate cell migration of atypical teratoid rhabdoid tumor through exosome-mediated miR155/SMARCA4 pathway. Cancers (Basel). (2019) 11:720. doi: 10.3390/cancers 11050720

108. Lu JQ, Wilson BA, Yong VW, Pugh J, Mehta V. Immune cell infiltrates in atypical teratoid/rhabdoid tumors. Can J Neurol Sci. (2012) 39:605-12. doi: $10.1017 / \mathrm{S} 031716710001533 \mathrm{X}$

109. Melcher V, Graf M, Interlandi M, Moreno N, de Faria FW, Kim SN, et al. Macrophage-tumor cell interaction promotes ATRT progression and chemoresistance. Acta Neuropathol. (2020) 139:913-36. doi: 10.1007/s00401019-02116-7

110. Jones C, Karajannis MA, Jones DTW, Kieran MW, Monje M, Baker SJ, et al. Pediatric high-grade glioma: biologically and clinically in need of new thinking. Neuro Oncol. (2016) 19:now101. doi: 10.1093/neuonc/ now101

111. Schwartzentruber J, Korshunov A, Liu X-Y, Jones DTW, Pfaff E, Jacob $\mathrm{K}$, et al. Driver mutations in histone H3.3 and chromatin remodelling 
genes in paediatric glioblastoma. Nature. (2012) 482:226-31. doi: 10.1038/ nature 10833

112. Wu G, Broniscer A, McEachron TA, Lu C, Paugh BS, Becksfort J, et al. Somatic histone $\mathrm{H} 3$ alterations in pediatric diffuse intrinsic pontine gliomas and non-brainstem glioblastomas. Nat Genet. (2012) 44:251-3. doi: 10.1038/ ng. 1102

113. Tate MC, Lindquist RA, Nguyen T, Sanai N, Barkovich AJ, Huang EJ, et al. Postnatal growth of the human pons: a morphometric and immunohistochemical analysis. J Comp Neurol. (2015) 523:449-62. doi: 10. 1002/cne. 23690

114. Braunstein S, Raleigh D, Bindra R, Mueller S, Haas-Kogan D. Pediatric highgrade glioma: current molecular landscape and therapeutic approaches. $J$ Neurooncol. (2017) 134:541-9. doi: 10.1007/s11060-017-2393-0

115. Cohen KJ, Pollack IF, Zhou T, Buxton A, Holmes EJ, Burger PC, et al. Temozolomide in the treatment of high-grade gliomas in children: a report from the Children's Oncology Group. Neuro Oncol. (2011) 13:317-23. doi: 10.1093/neuonc/noq191

116. Khuong-Quang D-A, Buczkowicz P, Rakopoulos P, Liu X-Y, Fontebasso AM, Bouffet E, et al. K27M mutation in histone H3.3 defines clinically and biologically distinct subgroups of pediatric diffuse intrinsic pontine gliomas. Acta Neuropathol. (2012) 124:439-47. doi: 10.1007/s00401-012-0998-0

117. Wolff JE, Rytting ME, Vats TS, Zage PE, Ater JL, Woo S, et al. Treatment of recurrent diffuse intrinsic pontine glioma: the MD anderson cancer center experience. J Neurooncol. (2012) 106:391-7. doi: 10.1007/s11060-0110677-3

118. Susheela SP, Revannasiddaiah S, Muzumder S, Mallarajapatna G, Kallur $\mathrm{K}$, Basavalingaiah AS. Re-irradiation with hypo-fractionated stereotactic robotic radiotherapy for salvage in adult patients with brainstem glioma. Ecancermedicalscience. (2013) 7:366. doi: 10.3332/ecancer.2013.366

119. Gwak H-S, Park HJ. Developing chemotherapy for diffuse pontine intrinsic gliomas (DIPG). Crit Rev Oncol Hematol. (2017) 120:111-9. doi: 10.1016/j. critrevonc.2017.10.013

120. Truffaux N, Philippe C, Paulsson J, Andreiuolo F, Guerrini-Rousseau L, Cornilleau G, et al. Preclinical evaluation of dasatinib alone and in combination with cabozantinib for the treatment of diffuse intrinsic pontine glioma. Neuro Oncol. (2015) 17:953-64. doi: 10.1093/neuonc/nou330

121. Long W, Yi Y, Chen S, Cao Q, Zhao W, Liu Q. Potential new therapies for pediatric diffuse intrinsic pontine glioma. Front Pharmacol. (2017) 8:495. doi: 10.3389/fphar.2017.00495

122. Pollack IF, Hamilton RL, James CD, Finkelstein SD, Burnham J, Yates AJ, et al. Rarity of PTEN deletions and EGFR amplification in malignant gliomas of childhood: results from the Children's Cancer Group 945 cohort. J Neurosurg Pediatr. (2006) 105:418-24. doi: 10.3171/ped.2006.105.5.418

123. Nakamura M, Shimada K, Ishida E, Higuchi T, Nakase H, Sakaki T, et al. Molecular pathogenesis of pediatric astrocytic tumors1. Neuro Oncol. (2007) 9:113-23. doi: 10.1215/15228517-2006-036

124. Bredel M, Pollack IF, Hamilton RL, James CD. Epidermal growth factor receptor expression and gene amplification in high-grade non-brainstem gliomas of childhood. Clin Cancer Res. (1999) 5:1786-92.

125. Wolff JEA, Driever PH, Erdlenbruch B, Kortmann RD, Rutkowski S, Pietsch $\mathrm{T}$, et al. Intensive chemotherapy improves survival in pediatric high-grade glioma after gross total resection: results of the HIT-gBM-c protocol. Cancer. (2010) 116:705-12. doi: 10.1002/cncr.24730

126. Donaldson SS, Laningham F, Fisher PG. Advances toward an understanding of brainstem gliomas. J Clin Oncol. (2006) 24:1266-72. doi: 10.1200/JCO. 2005.04.6599

127. Paugh BS, Qu C, Jones C, Liu Z, Adamowicz-Brice M, Zhang J, et al. Integrated molecular genetic profiling of pediatric high-grade gliomas reveals key differences with the adult disease. J Clin Oncol. (2010) 28:3061-8. doi: 10.1200/JCO.2009.26.7252

128. Paugh BS, Broniscer A, Qu C, Miller CP, Zhang J, Tatevossian RG, et al. Genome-wide analyses identify recurrent amplifications of receptor tyrosine kinases and cell-cycle regulatory genes in diffuse intrinsic pontine glioma. $J$ Clin Oncol. (2011) 29:3999-4006. doi: 10.1200/JCO.2011.35.5677

129. Buczkowicz P, Hoeman C, Rakopoulos P, Pajovic S, Letourneau L, Dzamba $\mathrm{M}$, et al. Genomic analysis of diffuse intrinsic pontine gliomas identifies three molecular subgroups and recurrent activating ACVR1 mutations. Nat Genet. (2014) 46:451-6. doi: 10.1038/ng.2936
130. Jin L, Ge H, Long Y, Yang C, Chang Y, Mu L, et al. CD70, a novel target of CAR T-cell therapy for gliomas. Neuro Oncol. (2018) 20:55-65. doi: 10.1093/neuonc/nox116

131. Shiina S, Ohno M, Ohka F, Kuramitsu S, Yamamichi A, Kato A, et al. CAR T cells targeting podoplanin reduce orthotopic glioblastomas in mouse brains. Cancer Immunol Res. (2016) 4:259-68. doi: 10.1158/2326-6066.CIR-15-0060

132. Ahmed N, Brawley V, Hegde M, Bielamowicz K, Kalra M, Landi D, et al. HER2-specific chimeric antigen receptor-modified virus-specific T cells for progressive glioblastoma: a phase 1 dose-escalation trial. JAMA Oncol.(2017) 3:1094-101. doi: 10.1001/jamaoncol.2017.0184

133. Lee Y, Martin-Orozco N, Zheng P, Li J, Zhang P, Tan H, et al. Inhibition of the B7-H3 immune checkpoint limits tumor growth by enhancing cytotoxic lymphocyte function. Cell Res. (2017) 27:1034-45. doi: 10.1038/cr.2017.90

134. Prasad DVR, Nguyen T, Li Z, Yang Y, Duong J, Wang Y, et al. Murine B7H3 is a negative regulator of T cells. J Immunol. (2004) 173:2500-6. doi: 10.4049/jimmunol.173.4.2500

135. Du H, Hirabayashi K, Ahn S, Kren NP, Montgomery SA, Wang X, et al. Antitumor responses in the absence of toxicity in solid tumors by targeting B7-H3 via chimeric antigen receptor T cells. Cancer Cell. (2019) 35:22137.e8. doi: 10.1016/j.ccell.2019.01.002

136. Chapoval AI, Ni J, Lau JS, Wilcox RA, Flies DB, Liu D, et al. B7-H3: a costimulatory molecule for $\mathrm{T}$ cell activation and IFN- $\gamma$ production. Nat Immunol. (2001) 2:269-74. doi: 10.1038/85339

137. Zhou Z, Luther N, Ibrahim GM, Hawkins C, Vibhakar R, Handler MH, et al. B7-H3, a potential therapeutic target, is expressed in diffuse intrinsic pontine glioma. J Neurooncol. (2013) 111:257-64. doi: 10.1007/s11060-012-1021-2

138. Mount CW, Majzner RG, Sundaresh S, Arnold EP, Kadapakkam M, Haile S, et al. Potent antitumor efficacy of anti-GD2 CAR T cells in H3-K27M+ diffuse midline gliomas. Nat Med. (2018) 24:572-9. doi: 10.1038/s41591-018-0006-x

139. Pule MA, Savoldo B, Myers GD, Rossig C, Russell HV, Dotti G, et al. Virusspecific T cells engineered to coexpress tumor-specific receptors: persistence and antitumor activity in individuals with neuroblastoma. Nat Med. (2008) 14:1264-70. doi: 10.1038/nm.1882

140. Louis CU, Savoldo B, Dotti G, Pule M, Yvon E, Myers GD, et al. Antitumor activity and long-term fate of chimeric antigen receptor-positive $\mathrm{T}$ cells in patients with neuroblastoma. Blood. (2011) 118:6050-6. doi: 10.1182/blood2011-05-354449

141. Heczey A, Louis CU, Savoldo B, Dakhova O, Durett A, Grilley B, et al. CAR T cells administered in combination with lymphodepletion and PD1 inhibition to patients with neuroblastoma. Mol Ther. (2017) 25:2214-24. doi: 10.1016/J.YMTHE.2017.05.012

142. Thomas S, Straathof K, Himoudi N, Anderson J, Pule M. An optimized GD2-targeting retroviral cassette for more potent and safer cellular therapy of neuroblastoma and other cancers. PLoS One. (2016) 11:e0152196. doi: 10.1371/journal.pone.0152196

143. Pollack IF, Jakacki RI, Butterfield LH, Hamilton RL, Panigrahy A, Potter $\mathrm{DM}$, et al. Antigen-specific immune responses and clinical outcome after vaccination with glioma-associated antigen peptides and polyinosinicpolycytidylic acid stabilized by lysine and carboxymethylcellulose in children with newly diagnosed malignant brainstem and N. J Clin Oncol. (2014) 32:2050-8. doi: 10.1200/JCO.2013.54.0526

144. Hegde M, Mukherjee M, Grada Z, Pignata A, Landi D, Navai SA, et al. Tandem CAR T cells targeting HER2 and IL13R $\alpha 2$ mitigate tumor antigen escape. J Clin Invest. (2016) 126:3036-52. doi: 10.1172/JCI83416

145. Brown CE, Alizadeh D, Starr R, Weng L, Wagner JR, Naranjo A, et al. Regression of glioblastoma after chimeric antigen receptor T-cell therapy. $N$ Engl J Med. (2016) 375:2561-9. doi: 10.1056/NEJMoa1610497

146. Funato K, Major T, Lewis PW, Allis CD, Tabar V. Use of human embryonic stem cells to model pediatric gliomas with H3.3K27M histone mutation. Science. (2014) 346:1529-33. doi: 10.1126/science.1253799

147. Monje M, Mitra SS, Freret ME, Raveh TB, Kim J, Masek M, et al. Hedgehogresponsive candidate cell of origin for diffuse intrinsic pontine glioma. Proc Natl Acad Sci USA. (2011) 108:4453-8. doi: 10.1073/pnas.110165 7108

148. Sturm D, Witt H, Hovestadt V, Khuong-Quang D-A, Jones DTW, Konermann C, et al. Hotspot mutations in H3F3A and IDH1 define distinct epigenetic and biological subgroups of glioblastoma. Cancer Cell. (2012) 22:425-37. doi: 10.1016/J.CCR.2012.08.024 
149. Lebel C, Gee M, Camicioli R, Wieler M, Martin W, Beaulieu C. Diffusion tensor imaging of white matter tract evolution over the lifespan. Neuroimage. (2012) 60:340-52. doi: 10.1016/J.NEUROIMAGE.2011.11.094

150. Patterson J, Wongsurawat T, Rodriguez A. A glioblastoma genomics primer for clinicians. Med Res Arch. (2020) 8:2034. doi: 10.18103/mra.v8i2.2034

151. Sottoriva A, Spiteri I, Piccirillo SGM, Touloumis A, Collins VP, Marioni JC, et al. Intratumor heterogeneity in human glioblastoma reflects cancer evolutionary dynamics. Proc Natl Acad Sci USA. (2013) 110:4009-14. doi: $10.1073 /$ pnas. 1219747110

152. Hambardzumyan D, Bergers G. Glioblastoma: defining tumor niches. Trends Cancer. (2015) 1:252-65. doi: 10.1016/j.trecan.2015.10.009

153. Daginakatte GC, Gutmann DH. Neurofibromatosis-1 (Nf1) heterozygous brain microglia elaborate paracrine factors that promote Nf1-deficient astrocyte and glioma growth. Hum Mol Genet. (2007) 16:1098-112. doi: $10.1093 / \mathrm{hmg} / \mathrm{ddm} 059$

154. Pong WW, Higer SB, Gianino SM, Emnett RJ, Gutmann DH. Reduced microglial CX3CR1 expression delays neurofibromatosis-1 glioma formation. Ann Neurol. (2013) 73:303-8. doi: 10.1002/ana.23813

155. Komohara Y, Ohnishi K, Kuratsu J, Takeya M. Possible involvement of the M2 anti-inflammatory macrophage phenotype in growth of human gliomas. J Pathol. (2008) 216:15-24. doi: 10.1002/path.2370

156. Kluiver TA, Alieva M, van Vuurden DG, Wehrens EJ, Rios AC. Invaders exposed: understanding and targeting tumor cell invasion in diffuse intrinsic pontine glioma. Front Oncol. (2020) 10:92. doi: 10.3389/fonc.2020.00092

157. Lieberman NAP, DeGolier K, Kovar HM, Davis A, Hoglund V, Stevens J, et al. Characterization of the immune microenvironment of diffuse intrinsic pontine glioma: implications for development of immunotherapy. Neuro Oncol. (2019) 21:83-94. doi: 10.1093/neuonc/noy145

158. Lin GL, Nagaraja S, Filbin MG, Suvà ML, Vogel H, Monje M. Noninflammatory tumor microenvironment of diffuse intrinsic pontine glioma. Acta Neuropathol Commun. (2018) 6:51. doi: 10.1186/s40478-018-0553-x

159. Sturm D, Bender S, Jones DTW, Lichter P, Grill J, Becher O, et al. Paediatric and adult glioblastoma: multiform (epi)genomic culprits emerge. Nat Rev Cancer. (2014) 14:92-107. doi: 10.1038/nrc3655

160. Gore L, Zugmaier G, Handgretinger R, Locatelli F, Trippett TM, Rheingold $\mathrm{SR}$, et al. Cytological and molecular remissions with blinatumomab treatment in second or later bone marrow relapse in pediatric acute lymphoblastic leukemia (ALL). J Clin Oncol. (2013) 31:10007-10007. doi: 10.1200/jco.2013. 31.15_suppl.10007

161. Frey NV, Porter DL. Cytokine release syndrome with novel therapeutics for acute lymphoblastic leukemia. Hematology. (2016) 2016:567-72. doi: 10. 1182/asheducation-2016.1.567

162. Thakar MS, Kearl TJ, Malarkannan S. Controlling cytokine release syndrome to harness the full potential of CAR-based cellular therapy. Front Oncol. (2020) 9:1529. doi: 10.3389/fonc.2019.01529

163. Maude SL, Barrett D, Teachey DT, Grupp SA. Managing cytokine release syndrome associated with novel T cell-engaging therapies. Cancer J. (2014) 20:119-22. doi: 10.1097/PPO.0000000000000035

164. Grupp SA, Kalos M, Barrett D, Aplenc R, Porter DL, Rheingold SR, et al. Chimeric antigen receptor-modified T cells for acute lymphoid leukemia. $N$ Engl J Med. (2013) 368:1509-18. doi: 10.1056/NEJMoa1215134

165. Teachey DT, Rheingold SR, Maude SL, Zugmaier G, Barrett DM, Seif AE, et al. Cytokine release syndrome after blinatumomab treatment related to abnormal macrophage activation and ameliorated with cytokine-directed therapy. Blood. (2013) 121:5154-7. doi: 10.1182/blood-2013-02-485623

166. Zhou X, Dotti G, Krance RA, Martinez CA, Naik S, Kamble RT, et al. Inducible caspase- 9 suicide gene controls adverse effects from alloreplete $\mathrm{T}$ cells after haploidentical stem cell transplantation. Blood. (2015) 125:410313. doi: 10.1182/blood-2015-02-628354

167. Gargett T, Brown MP. The inducible caspase- 9 suicide gene system as a "safety switch" to limit on-target, off-tumor toxicities of chimeric antigen receptor T cells. Front Pharmacol. (2014) 5:235. doi: 10.3389/fphar.2014. 00235

168. Brudno JN, Kochenderfer JN. Recent advances in CAR T-cell toxicity: Mechanisms, manifestations and management. Blood Rev. (2019) 34:45-55. doi: 10.1016/j.blre.2018.11.002

169. Lee DW, Santomasso BD, Locke FL, Ghobadi A, Turtle CJ, Brudno JN, et al. ASTCT consensus grading for cytokine release syndrome and neurologic toxicity associated with immune effector cells. Biol Blood Marrow Transplant. (2019) 25:625-38. doi: 10.1016/j.bbmt.2018.12.758

170. Yakoub-Agha I, Chabannon C, Bader P, Basak GW, Bonig H, Ciceri $\mathrm{F}$, et al. Management of adults and children undergoing chimeric antigen receptor T-cell therapy: Best practice recommendations of the European Society for Blood and Marrow Transplantation (EBMT) and the Joint Accreditation Committee of ISCT and EBMT (JACIE). Haematologica. (2020) 105:297-316. doi: 10.3324/haematol.2019.22 9781

171. Grigor EJM, Fergusson D, Kekre N, Montroy J, Atkins H, Seftel MD, et al. Risks and benefits of chimeric antigen receptor T-cell (CAR-T) therapy in cancer: a systematic review and meta-analysis. Transfus Med Rev. (2019) 33:98-110. doi: 10.1016/j.tmrv.2019.01.005

172. Graber JJ, Kesari S. Leptomeningeal metastases. Curr Treat Options Oncol. (2018) 19:3. doi: 10.1007/s11864-018-0518-0

173. O’Rourke DM, Nasrallah MP, Desai A, Melenhorst JJ, Mansfield K, Morrissette JJD, et al. A single dose of peripherally infused EGFRvIII-directed CAR T cells mediates antigen loss and induces adaptive resistance in patients with recurrent glioblastoma. Sci Transl Med. (2017) 9:eaaa0984. doi: 10.1126/ scitranslmed.aaa0984

174. Topalian SL, Hodi FS, Brahmer JR, Gettinger SN, Smith DC, McDermott DF, et al. Safety, activity, and immune correlates of anti-PD-1 antibody in cancer. N Engl J Med. (2012) 366:2443-54. doi: 10.1056/NEJMoa1200690

175. Okada H, Weller M, Huang R, Finocchiaro G, Gilbert MR, Wick W, et al. Immunotherapy response assessment in neuro-oncology: a report of the RANO working group. Lancet Oncol. (2015) 16:e534-42. doi: 10.1016/S14702045(15)00088-1

176. Eisele SC, Wen PY, Lee EQ. Assessment of brain tumor response: RANO and its offspring. Curr Treat Options Oncol. (2016) 17:35. doi: 10.1007/s11864016-0413-5

177. Topalian SL, Sznol M, McDermott DF, Kluger HM, Carvajal RD, Sharfman $\mathrm{WH}$, et al. Survival, durable tumor remission, and long-term safety in patients with advanced melanoma receiving nivolumab. J Clin Oncol. (2014) 32:1020-30. doi: 10.1200/JCO.2013.53.0105

178. Okada H, Kalinski P, Ueda R, Hoji A, Kohanbash G, Donegan TE, et al. Induction of CD8+ T-cell responses against novel glioma-associated antigen peptides and clinical activity by vaccinations with \{alpha\}-type 1 polarized dendritic cells and polyinosinic-polycytidylic acid stabilized by lysine and carboxymethylcellulose in. J Clin Oncol. (2011) 29:330-6. doi: 10.1200/JCO. 2010.30.7744

179. Wolchok JD, Hoos A, O’Day S, Weber JS, Hamid O, Lebbe C, et al. Guidelines for the evaluation of immune therapy activity in solid tumors: immunerelated response criteria. Clin Cancer Res. (2009) 15:7412-20. doi: 10.1158/ 1078-0432.CCR-09-1624

180. Kruit WHJ, van Ojik HH, Brichard VG, Escudier B, Dorval T, Dréno B, et al. Phase $1 / 2$ study of subcutaneous and intradermal immunization with a recombinant MAGE-3 protein in patients with detectable metastatic melanoma. Int J Cancer. (2005) 117:596-604. doi: 10.1002/ijc. 21264

181. Van Baren N, Bonnet M-C, Dréno B, Khammari A, Dorval T, PipernoNeumann S, et al. Tumoral and immunologic response after vaccination of melanoma patients with an ALVAC virus encoding MAGE antigens recognized by T cells. J Clin Oncol. (2005) 23:9008-21. doi: 10.1200/JCO. 2005.08.375

182. He Q, Jiang X, Zhou X, Weng J. Targeting cancers through TCRpeptide/MHC interactions. J Hematol Oncol. (2019) 12:1-17. doi: 10.1186/ s13045-019-0812-8

183. Habib R, Nagrial A, Micklethwaite K, Gowrishankar K. Chimeric antigen receptors for the tumour microenvironment. Adv Exp Med Biol. (2020) 1263:117-43. doi: 10.1007/978-3-030-44518-8_8

184. Schmitz F, Wolf D, Holderried TAW. The role of immune checkpoints after cellular therapy. Int J Mol Sci. (2020) 21:3650. doi: 10.3390/ijms 2110 3650

185. Habib S, Tariq SM, Tariq M. Chimeric antigen receptor-natural killer cells: the future of cancer immunotherapy. Ochsner J. (2019) 19:186-7. doi: 10.31486/ toj. 19.0033

186. Ravanpay AC, Gust J, Johnson AJ, Rolczynski LS, Cecchini M, Chang CA, et al. EGFR806-CAR T cells selectively target a tumor-restricted EGFR 
epitope in glioblastoma. Oncotarget. (2019) 10:7080-95. doi: 10.18632/ oncotarget.27389

187. Sibilia M, Kroismayr R, Lichtenberger BM, Natarajan A, Hecking M, Holcmann M. The epidermal growth factor receptor: from development to tumorigenesis. Differentiation. (2007) 75:770-87. doi: 10.1111/j.1432-0436. 2007.00238.x

188. Cheresh DA, Pierschbacher MD, Herzig MA, Mujoo K. Disialogangliosides GD2 and GD3 are involved in the attachment of human melanoma and neuroblastoma cells to extracellular matrix proteins. J Cell Biol. (1986) 102:688-96. doi: 10.1083/jcb.102. 3.688

189. Brown CE, Starr R, Martinez C, Aguilar B, D’Apuzzo M, Todorov I, et al. Recognition and killing of brain tumor stem-like initiating cells by CD8+ cytolytic T cells. Cancer Res. (2009) 69:8886-93. doi: 10.1158/0008-5472. CAN-09-2687

190. Brown CE, Starr R, Aguilar B, Shami AF, Martinez C, D’Apuzzo M, et al. Stem-like tumor-initiating cells isolated from IL13R 2 expressing gliomas are targeted and killed by IL13-zetakine-redirected T cells. Clin Cancer Res. (2012) 18:2199-209. doi: 10.1158/1078-0432.CCR-111669
191. Yi Z, Prinzing BL, Cao F, Gottschalk S, Krenciute G. Optimizing EphA2-CAR T Cells for the Adoptive Immunotherapy of Glioma. Mol Ther Methods Clin Dev. (2018) 9:70-80. doi: 10.1016/j.omtm.2018.01.009

192. Chow KKH, Naik S, Kakarla S, Brawley VS, Shaffer DR, Yi Z, et al. T cells redirected to EphA2 for the immunotherapy of glioblastoma. Mol Ther. (2013) 21:629-37. doi: 10.1038/mt.2012.210

Conflict of Interest: The authors declare that the research was conducted in the absence of any commercial or financial relationships that could be construed as a potential conflict of interest.

The handling Editor declared a past co-authorship with one of the authors $\mathrm{KB}$.

Copyright (c) 2020 Patterson, Henson, Breese, Bielamowicz and Rodriguez. This is an open-access article distributed under the terms of the Creative Commons Attribution License (CC BY). The use, distribution or reproduction in other forums is permitted, provided the original author(s) and the copyright owner(s) are credited and that the original publication in this journal is cited, in accordance with accepted academic practice. No use, distribution or reproduction is permitted which does not comply with these terms. 